\title{
Beyond formal powers: Understanding the African Union's authority on the ground
}

\author{
Antonia Witt* (D) \\ Peace Research Institute Frankfurt (PRIF), Frankfurt, Germany \\ ${ }^{\star}$ Corresponding author. Email: witt@hsfk.de
}

(Received 9 September 2020; revised 23 December 2021; accepted 17 January 2022; first published online 28 February 2022)

\begin{abstract}
International organisations (IOs) are said to command growing levels of authority. But in studying this phenomenon, scholars predominantly focus on the formal capacities member states assign to IOs. Much less attention is paid to the effects of IO authority, that is, how authority is exerted in practice and what it does within the affected societies. Based on a case study of the African Union's (AU) anti-coup regime, I make the case for a 'bottom-up' approach to IO authority, focusing on its localised enactment and effects. Analysing the AU's authority through a governmentality lens and drawing on several months of field research, I show that the AU's authority to govern coups is indeed effective: in commanding the re-establishment of constitutional order, the AU prescribes a particular imaginary of political order to resolve conflict and shapes the conduct of political actors in affected states by inscribing them into this order. But rather than operating in a top-down, direct way, the AU's authority is enacted in a distant, diffuse manner. Although based on formal powers assigned to the AU, neither the way this authority is exercised nor its effects can be inferred merely from these formal powers.
\end{abstract}

Keywords: International Organisations; Authority; Governmentality; African Union; Madagascar

\section{Introduction}

International Relations (IR) scholars are increasingly interested in studying the presence and consequences of authority in the international realm, particularly as these are specified in the expansive powers of international organisations (IOs) to set rules, to take binding decisions, and to implement and monitor policies independently. ${ }^{1}$

Authority is generally understood as a relationship of super- and subordination, where one actor has the right to command and require deference from others. ${ }^{2}$ In contrast to the classical understanding of power - which refers to the capacity of one actor to impose deference even against the other's will - authority denotes a more specific relationship of super- and subordination that rests on the general recognition of the right to direct others on specifically defined

\footnotetext{
${ }^{1}$ Michael Barnett and Martha Finnemore, Rules for the World: International Organizations in Global Politics (Ithaca, NY: Cornell University Press, 2004); Ole J. Sending, The Politics of Expertise: Competing Authority in Global Governance (Ann Arbor, MI: University of Michigan Press, 2015); Liesbet Hooghe et al., Measuring International Authority: A Postfunctionalist Theory of Governance, Volume III (Oxford, UK: Oxford University Press, 2017); Michael Zürn, A Theory of Global Governance: Authority, Legitimacy, and Contestation (Oxford, UK: Oxford University Press, 2018); Christian Kreuder-Sonnen, Emergency Powers of International Organizations (Oxford, UK: Oxford University Press, 2019).

${ }^{2}$ Max Weber, Wirtschaft und Gesellschaft (Tübingen, Germany: Mohr Siebeck, 1968 [orig. pub. 1921/22]); John Day, 'Authority', Political Studies, 11:3 (1963), pp. 257-71; Steven Lukes, 'Perspectives on authority', Nomos, 29 (1987), pp. 59-75.

(C) The Author(s), 2022. Published by Cambridge University Press on behalf of the British International Studies Association. This is an Open Access article, distributed under the terms of the Creative Commons Attribution licence (https://creativecommons.org/licenses/by/4.0/), which permits unrestricted re-use, distribution, and reproduction in any medium, provided the original work is properly cited.
} 
issues. $^{3}$ However, when studying the authority of IOs, IR scholars have so far primarily focused on understanding where this authority comes from, that is, they are predominantly concerned with detecting the sources of authority as reflected in the (expansive) formal powers of international organisations. Much less attention is paid to understanding how this authority is exercised and what it does within the societies and among the individuals affected. In other words, there is still an analytical and empirical research gap concerning how and with what consequences international authority is put into practice. Based on an in-depth case study of the African Union's (AU) authority to govern coups d'état and to enforce continental political norms, I seek to contribute to addressing this lacuna. The African Union's authority in this field is based on formal powers AU member states have assigned to the continental organisation. However, as I will show, neither the effects of this authority nor the way it is exercised can be inferred merely from these formal powers.

In July 2000 the Assembly of Heads of State and Government of the Organisation of African Unity (OAU), the AU's predecessor, took a far-reaching decision: in light of a growing number of coups d'état on the continent, they decided that from that day onward governments that come to power by extra-constitutional means should not be recognised and consequently be banned from participating in the continental organisation. ${ }^{4}$ Moreover, member states also mandated the OAU, its Secretary-General in particular, to work as quickly as possible on re-establishing constitutional order in the country concerned by negotiating with the putschists, mobilising international support, and if necessary applying economic and political sanctions. With the birth of this African anti-coup regime, the OAU/AU acquired a twofold authority: to define standards for legitimate order in African states and to regulate the conduct of those seeking to infringe upon these standards. Since then, this authority has been exercised in a total of 18 instances. ${ }^{5}$

But how is the African Union's authority to govern coups exercised in practice and what does it do 'on the ground'? With this article I aim to provide answers to both questions. For this purpose, I look closely at one concrete case, that is, the almost five years of African regional postcoup intervention in Madagascar (2009-14). In seeking to provide an answer to both questions, I analyse IO authority through a governmentality lens, which emphasises the role of governmental rationalities and techniques and their effects on the formation of subjects and the conduct of those affected by it through inclusion rather than control. ${ }^{6}$ As I will demonstrate with the case of Madagascar, the AU's authority to govern coups effectively served to prescribe a particular model of legitimate order that heavily circumscribed how and by whom Malagasies will be governed in the years to come. Yet in so doing and in promoting 'ownership' and 'inclusivity', it drew on the active participation of a particular section of the Malagasy elite who became inscribed in reordering Madagascar. Altogether, the AU's authority to govern coups was not exercised in a direct, top-down way based on command or even coercion, but operated in a distant and diffuse manner, involving a wide range of national and international actors in remaking constitutional order in Madagascar in this particular way.

The case of Madagascar is particularly suitable for studying the practices and effects of the AU's authority to govern coups. On the one hand, Madagascar was the longest lasting post-coup intervention under the African anti-coup regime. The length of the intervention reflects the difficulties of realising the AU's claim to the governing of coups. It thus demonstrates the analytical

\footnotetext{
${ }^{3}$ Weber, Wirtschaft und Gesellschaft, $\$ 16$.

${ }^{4}$ Organisation of African Unity (OAU), Declaration on the Framework for an OAU Response to Unconstitutional Changes of Government, AHG/Decl.5 (XXXVI) (Lomé, Togo: Organisation of African Unity, 2000).

${ }^{5}$ Issaka K. Souaré, 'The African Union as a norm entrepreneur on military coups d'état in Africa (1952-2012): An empirical assessment', Journal of Modern African Studies, 52:1 (2014), pp. 69-94.

${ }^{6}$ Michel Foucault, Sicherheit, Territorium, Bevölkerung: Geschichte der Gouvernementalität I (Frankfurt am Main, Germany: Suhrkamp, 2004 [orig. pub. 1978]); Michel Foucault, The Birth of Biopolitics: Lectures at the Collège de France 1978-79 (Basingstoke, UK: Palgrave Macmillan, 2008 [orig. pub. 1988]).
} 
limits of understanding IO authority based on purely formal capacities and consequently offers an opportunity to empirically reconstruct the distant and diffuse way in which the AU's authority was eventually put into practice. On the other hand, and with regard to the observable effects of AU authority, the case of Madagascar follows a more general pattern in which African regional post-coup interventions promote a particular model of political order that is prescriptive and inscriptive at the same time. It is thus a particularly pertinent case for studying these effects in more detail. ${ }^{7}$

In scrutinising the enactment and effects of the AU's authority to govern coups, I aim to contribute to existing scholarship in two ways. First, the 'bottom-up' approach taken in this article makes it possible to scrutinise the effects rather than the sources of international authority, that is, understanding international authority as it materialises in very concrete locales and the way it shapes subjectivities and thus affects the scope of action of a variety of actors in the societies concerned. Such an approach does conceptual justice to Michael Zürn's observation that today global governance has a double constituency: states, on the one hand, as well as societies and individuals, on the other, are targeted by the rule-setting aims of international authority and thus have both rights and obligations under the global governance system currently in place. ${ }^{8}$ Yet, so far IR scholarship has mostly been focused on the first - the state constituency and has neglected the latter, unless it has become visible through public mobilisation and protest. 9

Second, in studying the case of the AU, I also seek to complement the existing literature's global focus by paying more attention to the growing relevance of regional organisations for the study of international authority. Most in-depth empirical works on international authority draw their conclusions from a few global organisations or the European Union (EU). ${ }^{10}$ This focus is surprising because, in fact, existing datasets demonstrate that across the globe, regional organisations have expanded their policy scope as well as their executive and adjudicatory capacities, and are thus prominent examples of the growing delegation and pooling of authority in institutions beyond the state. ${ }^{11}$ While this justifies the relevance for studying the authority of regional organisations like the AU, it is arguably not sufficient for understanding how this authority operates and what it does.

Empirically, this article draws on more than ten months of field research between 2012 and 2014 and is based on interviews, archival research, and participant observation at the AU headquarters in Addis Ababa, Ethiopia, the headquarters of the Southern African Development Community (SADC) in Gaborone, Botswana, and in Madagascar. This is supplemented by official and unofficial AU/SADC documents, primary sources from the conflict parties in Madagascar, as well as media reports.

The remainder of this article is structured as follows. The next section explains the AU's formal authority to govern coups as enshrined in the African anti-coup regime. The third section argues that scholarship on IO authority has predominantly approached authority through a 'sovereign imaginary', focusing on the formal capacities of those assumed to hold authority and thus neglecting practical effects. As an alternative, the fourth section makes the case for studying IO

\footnotetext{
${ }^{7}$ Antonia Witt, Undoing Coups: The African Union and Post-coup Intervention in Madagascar (London, UK: Zed Books, 2020), p. 207.

${ }^{8}$ Zürn, A Theory of Global Governance, p. 177.

${ }^{9}$ Michael Zürn, Martin Binder, and Matthias Ecker-Ehrhardt, 'International authority and its politicization', International Theory, 4:1 (2012), pp. 69-106.

${ }^{10}$ But see Yoram Z. Haftel and Stephanie C. Hofmann, 'Institutional authority and security cooperation within regional economic organizations', Journal of Peace Research, 54:4 (2017), pp. 484-98.

${ }^{11}$ Gary Goertz and Kathy Powers, 'Regional Governance: The Evolution of a New Institutional Form', WZB Discussion Paper SP IV 2014-106 (Berlin: Wissenschaftszentrum Berlin für Sozialforschung, 2014); Hooghe et al., Measuring International Authority; Michael Zürn, Alexandros Tokhi, and Martin Binder, 'The international authority database', Global Policy, online first (2021).
} 
authority through a governmentality lens, highlighting the diffuse enactment of governmental rationalities and practices and their enabling and at the same time constraining effects on the conduct of those addressed. The fifth section focuses on the enactment of AU's authority to govern coups in the case of Madagascar and explains both the rationales involved in restoring constitutional order as well as the subjectivating effects this had on a particular section of the Malagasy elite and on politics on the island more generally. The AU's formal powers were crucial but not sufficient for understanding either these effects or the exercise of AU authority. In the conclusion I summarise my argument and draw some lessons for future IR research on authority in the international realm.

\section{The African Union's authority to govern coups d'état}

For most of Africa's postcolonial history, the governance of African states was not a matter of continental concern. Since the early 1990s, this has changed dramatically, driven by various efforts to define continental standards for what counts as legitimate order and what to do in cases where these standards are not upheld. The African anti-coup regime that outlaws coups d'état is only one example. ${ }^{12}$ These developments not only led to the definition of new norms on how African states ought to be governed, but they also implied an increase in authority for the continental organisation.

In July 2000, African heads of state and government adopted the so-called Lomé Declaration, in which coups d'état were defined as a threat to the continent's progress towards peace, security, and democracy. ${ }^{13}$ The OAU Assembly decided to henceforth outlaw any government that came to power by unconstitutional means by suspending its membership from the continental organisation. It also required the OAU Secretary-General to 'facilitate the restoration of constitutional order' within six months by engaging the perpetrators 'with a view to ascertaining their intentions regarding the restoration of constitutional order'. ${ }^{14}$ If these efforts remained ineffective, more coercive means such as individual targeted sanctions should be applied. ${ }^{15}$ In all these efforts, the Lomé Declaration requires the OAU Secretary-General to enlist support from OAU member states as well as the wider international/donor community. ${ }^{16}$

The continental anti-coup regime was an attempt to discipline governance in OAU member states and to establish people's right to choose how and by whom they are governed as standard in all African states. The need for such a continental standard was justified by reference to the shared responsibility of 'Africa', of which the OAU was the organisational embodiment. ${ }^{17}$ The drafting of the anti-coup regime was a collective effort driven by the OAU Secretariat as well as international and African non-state actors, but it ultimately depended on the acceptance and support of OAU member states. However, contrary to the narrative of a shared responsibility of 'Africa', OAU member states were in fact heavily divided as to whether an anti-coup regime should be put in place and what form it should take. In preparatory meetings, debate focused on, for instance, whether constitutional revisions to prolong an incumbent's stay in power constitute a coup d'état and should hence be sanctioned, or whether the text should include an open clause that allows adding future scenarios to the list of situations counted as unconstitutional

\footnotetext{
${ }^{12}$ African Union (AU), African Charter for Democracy, Elections, and Governance (Addis Ababa, Ethiopia: African Union, 2007); Thomas K. Tieku, 'Multilateralization of democracy promotion and defense in Africa', Africa Today, 56:2 (2007), pp. 75-91.

${ }^{13}$ OAU, Declaration on the Framework.

${ }^{14}$ Ibid.

${ }^{15} \mathrm{Ibid}$.

${ }^{16}$ Ibid.

${ }^{17}$ 'OAU condemns coup in Burundi', Reuters (1993), available at: \{https://global.factiva.com/ha/default.aspx\#./!? \&_suid=144862119146401004177967552095\}; 'OAU Secretary-General in Rwanda, says that something has to be done for Burundi’, BBC (1993), available at: \{https:/global.factiva.com/ha/default.aspx\#./!?\&_suid=144862194405803351135831326246\}.
} 
change of government. ${ }^{18}$ These debates demonstrate that at least some African states were hesitant to transfer too much power to interfere in domestic politics to the OAU. ${ }^{19}$ The final text of the Lomé Declaration is thus a compromise in which several ideas that would have given the OAU a more intrusive political role were not included. ${ }^{20}$ In the end, however, the document adopted still grants considerable authority to the continental organisation to define how African state should (not) be governed.

With the transformation of the OAU into the African Union in 2002, this authority was further expanded and legalised. The AU's Constitutive Act reiterates that 'governments which shall come to power through unconstitutional means shall not be allowed to participate in the activities of the Union. ${ }^{21}$ With the adoption of the African Charter on Democracy, Elections and Governance in 2007 the African anti-coup regime became binding continental law and the AU was further authorised to apply sanctions against perpetrators of coups and against other AU member states supporting them. ${ }^{22}$ The power to identify an instance of an unconstitutional change of government and to impose sanctions against countries affected by such situations and the individuals responsible for it rests with the 15 -member Peace and Security Council (PSC). ${ }^{23}$ Decisions by the PSC are binding and can in such cases be taken even without the consent of the state concerned. ${ }^{24}$ The PSC is also required to decide whether constitutional order has been restored and when to lift a country's suspension. In carrying out these tasks, the PSC is supported by staff of the AU Commission's Political Affairs, Peace and Security Department who prepare PSC meetings and missions, draft decisions, and provide expertise on the situation in the countries concerned. ${ }^{25}$

In sum, the African anti-coup regime provides the AU with twofold authority. First, it gives the continental organisation - its PSC more specifically - the formal authority to judge political events in $\mathrm{AU}$ member states and to identify infringements against shared standards. Second, the AU has the formal authority to ensure the re-establishment of constitutional 'normalcy' in situations in which this normalcy has been interrupted. In demanding a 'speedy return to constitutional order ${ }^{\text {'2 }}$ the AU claims authority over the conduct of putschists and political actors in the member states concerned as well as over the conduct of other international actors who are required to align with the AU's position and to support the re-establishment of constitutional order in the case in question.

\section{Studying the authority of international organisations}

Over the last decade, IR scholars have become increasingly interested in the multiple forms of super- and subordination existing in the international realm that result from formal and informal rules and institutions. ${ }^{27}$ International organisations have taken a prominent position in this

\footnotetext{
${ }^{18} \mathrm{OAU}$, Report of the Sub-Committee of the Central Organ on Unconstitutional Changes in Africa (Lomé, Togo: Organisation of African Unity, 2000); OAU Secretariat, Report of the Secretary-General on the Implementation of the Algiers Decisions of the Assembly of Heads of State and Government and the Council of Ministers on Unconstitutional Changes of Government, CM/2166(LXXII) Rev. 2 (Lomé, Togo: Organisation of African Unity, 2000).

${ }^{19}$ See also Micha Wiebusch, Chika Charles Aniekwe, Lutz Oette, and Stef Vandeginste, 'The African Charter on Democracy, Elections and Governance: Past, present and future', Journal of African Law, 63:S1 (2019), pp. 9-38.

${ }^{20}$ Witt, Undoing Coups, ch. 2.

${ }^{21} \mathrm{OAU}$, Constitutive Act of the African Union (Lomé, Togo: Organisation of African Unity, 2000), Art. 30.

${ }^{22} \mathrm{AU}$, African Charter, Art. 25.

${ }^{23} \mathrm{AU}$, Protocol Relating to the Establishment of the Peace and Security Council of the African Union (Durban, South Africa: African Union, 2002), Art. 7(1g); AU, African Charter, Art. 24.

${ }^{24}$ AU, Protocol Relating, Art. 7(3).

${ }^{25}$ Heidi Hardt, 'From states to secretariats: Delegation and the African Peace and Security Council', African Security, 9:3 (2016), pp. 161-87.

${ }^{26}$ OAU, Declaration on the Framework.

${ }^{27}$ See, for instance, David A. Lake, 'Rightful rules: Authority, order, and the foundations of global governance', International Studies Quarterly, 54:3 (2010), pp. 587-613; Ayșe Zarakol (ed.), Hierarchies in World Politics (Cambridge, UK: Cambridge University Press, 2017); Zürn, A Theory of Global Governance; Felix Anderl et al. (eds), Rule and Resistance Beyond the Nation
} 
research agenda, based on the observation that IOs hold and exercise authority. Rather than being mere forums for intergovernmental politics, IOs have become global governors whose norms, ideas, and policies bring about order and structure actors' behaviour not only internationally but also within states. ${ }^{28}$

In the growing literature on the authority of IOs, the main focus has so far been on identifying the sources of this authority. For some authors, IO authority stems from the formal capacities member states have delegated to or the pooling of decision-making functions in international organisations. ${ }^{29}$ Others draw attention more broadly to the increasing institutional and legal capacities of international organisations to set policy agendas, take binding decisions, adjudicate, and implement policies. ${ }^{30}$ A more constructivist and sociological perspective attributes the authority of IOs to their character as bureaucracies and their ability to construct problems, make rules, define adequate solutions, and allocate responsibilities. Apart from formal and legal capacities, such scholarship also highlights the moral and epistemic sources of IO authority. ${ }^{31}$ Despite the breadth of theoretical approaches in this literature, the study of IO authority is still circumscribed in two regards, which unnecessarily limit IR scholars' grasp of the actual magnitude and presence of the authority of international organisations.

Firstly, the authority of IOs has mainly been conceived of within a 'sovereign imaginary', that is, as authority with characteristics similar to domestic state authority. As noted by Nico Krisch, most of the literature on international authority has simply adopted the 'command model' of domestic authority of states, understood as 'the exercise of binding powers to create formal obligations', and transplanted it to the international realm. ${ }^{32}$ This reflects the more general and still dominant tradition in IR scholarship of understanding power in global governance predominantly in terms of what Stefano Guzzini called 'agential ordering', or what Michael Barnett and Raymond Duvall identified as 'compulsory power'. ${ }^{33}$ Both these approaches focus on the steering capacities of particular actors and their direct effects on others. Much of the search for understanding the changing role of IOs is therefore dedicated to showing the relative power they command vis- $\dot{a}$-vis the state. This is reflected not least in the concrete definitions of IO authority, for instance as 'authority independent of their member states' ${ }^{34}$ or as autonomy vis-à-vis states. ${ }^{35}$ This also means that IO authority is often (if only implicitly) defined as alternative and/or a challenge to the state. ${ }^{36}$ Thus the state remains the epistemological starting point and backdrop against which authority in the international realm becomes visible, and this authority is often imagined as a zero-sum game.

State: Contestation, Escalation, Exit (London, UK: Rowman \& Littlefield International, 2019); Nicole Deitelhoff and Christopher Daase, 'Rule and resistance in global governance', International Theory, 13:1 (2021), pp. 122-30.

${ }^{28}$ Barnett and Finnemore, Rules; Deborah D. Avant, Martha Finnemore, and Susan K. Sell (eds), Who Governs the Globe? (Cambridge, UK: Cambridge University Press, 2010); Anne Orford, International Authority and the Responsibility to Protect (Cambridge, UK: Cambridge University Press, 2011); Sending, The Politics of Expertise; Zürn, A Theory of Global Governance.

${ }^{29}$ Liesbet Hooghe and Gary Marks, 'Delegation and pooling in international organizations', Review of International Organizations, 10:3 (2015), pp. 305-28 (p. 307); Hooghe et al., Measuring International Authority.

${ }^{30}$ Zürn et al., 'International authority', p. 70; Zürn et al., 'The international authority', p. 2.

${ }^{31}$ Barnett and Finnemore, Rules, p. 3; Deborah D. Avant, Martha Finnemore, and Susan K. Sell, 'Who governs the globe', in Avant, Finnemore, and Sell (eds), Who Governs, pp. 9-14.

${ }^{32} \mathrm{Nico}$ Krisch, 'Liquid authority in global governance', International Theory, 9:2 (2017), pp. 237-60 (p. 237).

${ }^{33}$ Stefano Guzzini, 'The ambivalent "diffusion of power" in global governance', in Stefano Guzzini and Iver B. Neumann (eds), The Diffusion of Power in Global Governance: International Political Economy Meets Foucault (Basingstoke, UK: Palgrave Macmillan, 2012), pp. 1-37 (pp. 4-5); Michael Barnett and Raymond Duvall, 'Power in global governance', in Michael Barnett and Raymond Duvall (eds), Power in Global Governance (Cambridge, UK: Cambridge University Press, 2008), pp. 1-32 (pp. 13-15). See also the critique of 'control power', in Peter J. Katzenstein and Lucia A. Seybert, 'Protean power and uncertainty: Exploring the unexpected in world politics', International Studies Quarterly, 62 (2018), pp. 80-93.

${ }^{34}$ Hooghe and Marks, 'Delegation and pooling', p. 305.

${ }^{35}$ Barnett and Finnemore, Rules, pp. 4-5; Zürn et al., 'The international authority', p. 2.

${ }^{36}$ Lake, 'Rightful rules', p. 600; Zürn et al., 'International authority', p. 70; see also Jorg Kustermans and Rikkert Horemans, 'Four conceptions of authority in International Relations', International Organization, online first (2021), pp. 1-25 (p. 17). 
Apart from ignoring those forms of authority not formally assigned to an IO, the 'sovereign imaginary' has two empirical-analytical limits. On the one hand, it tends to conceal how the state is reproduced through the expansion of international authority, for instance through the definition of sovereignty principles and interventions by international institutions aimed at reconstructing states' empirical sovereignty. ${ }^{37}$ On the other hand, understanding IO authority solely through the lens of the state also assigns secondary importance to the question how international authority is exercised over others, such as societies, groups of people, and individuals affected by IO norms and governance practices. The few prominent examples in which international authority has been specifically discussed as authority vis-à-vis societies or groups of people are situations in which international organisations function as transitional authorities and thus even officially act in the name of the state. ${ }^{38}$ Yet, what has so far received much less attention is how international organisations govern subjects other than states along with and through the state, for instance by programming health systems, assigning refugee status, constructing 'civil societies', and training police and security services. ${ }^{39}$ Altogether, the 'sovereign imaginary' thus fails to reflect the more complex social configurations of the international and neglects the manifold ways in which power can be exercised in global governance beyond direct command through formal powers. ${ }^{40}$

Secondly, the literature has so far paid only little attention to investigating the exercise, and with this the broader effects of, IO authority. In fact, it is often simply assumed that international authority exists and is effective, that is, having an effect. This can be attributed to the still dominant focus on formal rules and institutions as sources of authority, which are by and of themselves considered powerful, irrespective of how and with what effects they are applied in practice. ${ }^{41}$ Consequently, in what follows and in order to focus on the exercise of IO authority, I propose examining IO authority through a governmentality lens. Such a perspective makes it possible to trace the relevance of international authority not by reference to formal rules and capacities assigned to IOs, but through the subjectivating, simultaneously enabling and constraining, effects of particular governmental rationalities.

\section{0 authority as governmentality}

So what does it mean to study the practices and effects of IO authority through a governmentality lens? Based on the works of Michel Foucault, his thinking about power in particular, a governmentality perspective explores the links between knowledge regimes and practices of government that affect the conduct of others and structure their 'possible field of action'. ${ }^{42}$ Governmentality thinking draws attention away from the formal capacities of those assumed to hold power and instead sheds light on the relational and productive side of power that works through the constitution of subjects. ${ }^{43}$

\footnotetext{
${ }^{37}$ Jens Bartelson, Sovereignty as Symbolic Form (Abingdon, UK: Routledge, 2014), p. 87.

${ }^{38}$ Simon Chesterman, You, the People: The United Nations, Transitional Administration, and State-Building (Oxford, UK: Oxford University Press, 2004); Dominik Zaum, 'The authority of international administrations in international society', Review of International Studies, 32:3 (2006), pp. 455-73.

${ }^{39}$ But, see for instance, James Ferguson, The Anti-Politics Machine (Minneapolis, MN: University of Minnesota Press, 1994); Graham Harrison, Neoliberal Africa: The Impact of Global Social Engineering (London, UK: Zed Books, 2010); Jon H. S. Lie, Developmentality: An Ethnography of the World Bank-Uganda Partnership (New York, NY: Berghahn, 2015); Phil Clark, Distant Justice: The Impact of the International Criminal Court on African Politics (Cambridge, UK: Cambridge University Press, 2019). These works and their insights, however, have so far remained disconnected from and largely ignored by IR scholarship on IO authority.

${ }^{40}$ Iver B. Neumann and Ole J. Sending, Governing the Global Polity: Practice, Mentality, Rationality (Ann Arbor, MI: University of Michigan Press, 2010); Barnett and Duvall, 'Power', p. 4; Guzzini, 'The ambivalent'.

${ }^{41}$ For a similar observation regarding the study of benchmarks, see Ole J. Sending and Jon H. S. Lie, 'The limits of global authority: World Bank benchmarks in Ethiopia and Malawi', Review of International Studies, $41: 5$ (2015), pp. 993-1010 (p. 994).

${ }^{42}$ Michel Foucault, 'The subject and power', Critical Inquiry, 8 (1982), pp. 777-95 (p. 790); Foucault, Sicherheit.

${ }^{43}$ For a discussion related to global governance, see Barnett and Duvall, 'Power', pp. 20-2; Guzzini, 'The ambivalent', pp. 21-7.
} 
A governmentality lens explores the constitution of social orders through the workings of political rationalities (mentality) that define how things ought to be done, how objects and subjects relate to one another, and how responsibilities should be distributed. In short, political rationalities reflect 'the reasoned way of governing best'. ${ }^{44}$ Such rationalities come with specific governmental techniques and practices that turn this mentality into practice and constitute social order. ${ }^{45}$ Political rationalities are hence not powerful in and of themselves, but are effective only in and through practice. In search for an answer to the question 'how we are governed', Foucault offers an insight into the productive workings of power, which gives centre stage to the small-scale practices that define who is a subject, assign responsibilities, and sustain and normalise relationships of difference in an often diffuse and non-subjective way. ${ }^{46}$ Key to this understanding of power is its subjectivating effect, which Foucault understands simultaneously as submission and the formation of subjects. Hence the implementation of governmental rationalities to regulate social and political life has both enabling and constraining effects on those governed. The power at work here is not a totalising, coercing one, but one that works through and with the subject addressed. Foucault thus explicitly differentiated governmentality from other forms of power that operate through discipline and control. Rather than coercing subjects into deference, governmentality secures deference through freedom and inclusion of those governed. ${ }^{47}$ This also means that resistance is always possible. ${ }^{48}$

Employing a governmentality perspective to study IO authority involves a certain stretching of the concept as it was originally formulated. For Foucault, governmentality was a lens for understanding the historical evolution of the European state and, later, the workings of a particular liberal form of government that focused on the government of populations through freedom and care. What is of interest here, however, is not the regulation of populations by states, but the regulation of states/governments through IO norms and policies with the aim of making them fit to govern their populations better and more legitimately. The transferability of the concept to the international realm has been the subject of a great deal of debate, ${ }^{49}$ but the relevance of such a transfer, specifically with regard to IOs, has also been demonstrated. ${ }^{50}$ In fact, Foucault himself operated with multiple understandings of governmentality. Accordingly, William Walters suggests treating the concept as an 'analytical toolbox', demanding 'encounters' instead of dogmatic 'application'. ${ }^{51}$ In this sense, the conceptual extension in this case, as in others before it, effectively serves to 'disengage the association of the governmentality perspective with the state and state power, ${ }^{52}$ while at the same time retaining the concept's key features in order to analyse new forms and constellations of governance under internationalised conditions.

In a practical sense, a governmentality lens turns the analytical gaze away from IOs' formal, legally prescribed capacities and turns to the governmental rationalities they produce and

\footnotetext{
${ }^{44}$ Foucault, The Birth, p. 2.

${ }^{45}$ Mitchell Dean, Governmentality: Power and Rule in Modern Society ( ${ }^{\text {nd }}$ edn, Los Angeles, CA: Sage, 2010); William Walters, Governmentality: Critical Encounters (Oxon, UK: Routledge, 2012).

${ }^{46}$ Foucault, Sicherheit; Walters, Governmentality, ch. 2.

${ }^{47}$ Barry Hindess, 'Politics as government: Michael Foucault's analysis of political reason', Alternatives, 30:4 (2005), pp. 389-413 (p. 392).

${ }^{48}$ Foucault, 'The subject and power', p. 780.

${ }^{49}$ See, for instance, Jonathan Joseph, 'Governmentality of what? Populations, states and international organisations', Global Society, 23:4 (2009), pp. 413-27; Doerthe Rosenow, 'Decentring global power: The merits of a Foucauldian approach to international relations', Global Society, 23:4 (2009), pp. 497-517; Carl Death, 'Governmentality at the limits of the international: African politics and Foucauldian theory', Review of International Studies, 39:3 (2013), pp. 763-87.

${ }^{50}$ Joseph, 'Governmentality'; Neumann and Sending, Governing the Global Polity;

${ }^{51}$ Walters, Governmentality, p. 3.

${ }^{52}$ Jon H. S. Lie, 'Local ownership as global governance', The European Journal of Development Research, 31:4 (2019), pp. 1107-25 (p. 1109).
} 
disseminate as well as the techniques and practices of intervention this renders possible. ${ }^{53}$ Ole Jacob Sending, for instance, demonstrates that behind formal capacities, IO authority is based on a struggle between competing experts and expertise that claim authority over defining what to govern globally, how, and why. ${ }^{54}$ Governance norms that define how states ought to be governed - such as laid down in the African anti-coup regime - are an increasingly important dimension of the way IOs formulate such governmental rationalities today. ${ }^{55}$ To establish, spread, and sustain specific imaginaries of what order should look like is thus a key aspect of IO authority, as I will demonstrate in the remainder of this article. Altogether, this capacity of IOs to define and disseminate governance norms on the basis of which authority over particular issues is exerted makes a governmentality perspective particularly relevant for the study of IO authority. Moreover, a governmentality perspective also renders visible the ambiguous effects the implementation of governmental rationalities may have on the formation of subjects, that is, subjectivation in the double sense. As summarised by Guzzini, in a governmentality perspective, 'power is diffused but not diluted.' It describes a mode of governance by which 'more agents have been 'empowered', [yet] this empowerment goes hand in hand with a widened and deepened system of rule that applies to and works through those very empowered agents. ${ }^{56}$ And finally, by studying power through its effects and not its sources, a governmentality lens allows reconstruction of the enactment of IO authority as an interaction with a great variety of other actors, thus avoiding the sovereign imaginary of IO authority as direct control and instead adapting the analytics to the complex and constrained forms of governance prevalent in the international realm.

\section{AU authority in practice}

On 20 March 2009, after weeks of public protest against the Malagasy President Marc Ravalomanana, the latter handed over power to a military directorate, which in turn installed the head of the protest movement, Andry Rajoelina, as president of the transition. Rajoelina and his government, the High Authority of the Transition (Haute autorité de la transition, HAT), announced the dissolution of all state institutions and promised to hold elections. The AU, the Southern African Development Community (SADC) and most of Madagascar's international donors condemned this act as an unconstitutional change of government. ${ }^{57}$ In line with the anti-coup regime, the AU PSC decided to suspend Madagascar's membership and instructed the chairperson of the AU Commission to 'contribute to the rapid restoration of constitutional order, and to take all the initiatives he deems necessary to this effect'. ${ }^{58}$ The SADC Organ on Politics, Defense and Security suspended Madagascar from the organisation and

\footnotetext{
${ }^{53}$ Michael Merlingen, 'Governmentality: Towards a Foucauldian framework for the study of IGOs', Cooperation \& Conflict, 38:4 (2003), pp. 361-84; Michael Merlingen and Rasa Ostrauskaite, 'Power/knowledge in international peacebuilding: The case of the EU Police Mission in Bosnia', Alternative: Global, Local, Political, 30:3 (2005), pp. 297-323; Laura Zanotti, Governing Disorder: UN Peace Operations, International Security, and Democratization in the Post-Cold War Era (University Park, PA: Pennsylvania State University Press, 2011); Helle Malmvig, 'Free us from power: Governmentality, counter-conduct, and simulation in European democracy and reform promotion in the Arab World', International Political Sociology, 8:3 (2014), pp. 293-310.

${ }^{54}$ Sending, The Politics of Expertise.

${ }^{55}$ Neumann and Sending, Governing, p. 136.

${ }^{56}$ Guzzini, 'The ambivalent', p. 2.

${ }^{57}$ African Union Peace and Security Council (AU PSC), Communiqué of the $181^{\text {st }}$ Meeting of the Peace and Security Council, PSC/PR/COMM (CLXXXI) (Addis Ababa, Ethiopia: African Union, 2009); Southern African Development Community (SADC), Extraordinary SADC Summit of Troika of the Organ on Politics, Defense and Security Cooperation of 19 March (Ezulwini, Eswatini: Southern African Development Community, 2009); SADC, Communiqué Summit of SADC Heads of State and Government (Sandton, Gauteng Province: Southern African Development Community, 2009).

${ }^{58} \mathrm{AU}$ PSC, Communiqué of the $181^{\text {st }}$ Meeting.
} 
suggested that SADC should 'use all relevant resources available to restore order in Madagascar'. ${ }^{59}$ Most of Madagascar's international donors withheld their development funds except for humanitarian assistance. The chairperson of the AU Commission appointed Ablassé Ouédraogo as mediator and special envoy to Rajoelina and the HAT government, 'ascertaining their intentions regarding the restoration of constitutional order' as foreseen in the anti-coup regime. ${ }^{60}$ In parallel, SADC, the United Nations, and the International Organisation de la Francophonie (OIF) sent their own special envoys to Antananarivo to work with the Malagasy parties. The African Union required that the return to constitutional order in Madagascar should be consensual, negotiated, and include both sides - the ousted President Ravalomanana and Rajoelina.

However, the AU's claim to authority over the conduct of both Malagasy and international actors did not materialise easily. On the one hand, Rajoelina and the HAT objected to the AU PSC's demand for rapid restoration of constitutional order. Immediately after taking power, the HAT government sent letters to the diplomatic communities in Addis Ababa, New York, and Paris and demanded recognition as the legitimate government of Madagascar. The putschists stressed the fact that unlike a (bad) military coup, they had come to power with the support of a 'movement populaire national' - a popular national movement - and thus represented a (good) civilian and democratic force. ${ }^{61}$ Hence Rajoelina's willingness to negotiate a transitional period with his rival Ravalomanana was limited and compromise at the negotiating table seemed unattainable, as numerous rounds of negotiations in 2009 and ensuing years confirmed. On the other hand, several international actors also failed to back the AU's demand to support efforts to restore constitutional order in Madagascar. In fact, what kind of transitional period and with whom should lead to restoring Malagasy constitutional order was a matter of disagreement among the multiple international actors involved in this process. Madagascar's former colonial power France, for instance, initially took a much more accommodating stance vis-à-vis Rajoelina and the HAT and would have accepted a transition to constitutional order without the participation of Ravalomanana. ${ }^{62}$ Like the HAT, the French Ministry of Foreign Affairs and Minister Bernard Kouchner in particular repeatedly spoke of a 'revolution' and a 'popular coup d'état', ${ }^{63}$ thus undermining the AU's interpretation of the situation. In contrast to this, the SADC Summit in late March 2009 demanded the 'unconditional reinstatement of President Ravalomanana' and even warned of the need to 'consider other options to restore constitutional normalcy', which was widely interpreted as a threat to use military force. ${ }^{64}$ Despite these varying international approaches to the situation in Madagascar, over the course of the first six months a consensus nevertheless emerged concerning the demand for the re-establishment of constitutional order through an inclusive, transparent and credible

\footnotetext{
${ }^{59}$ SADC, Extraordinary SADC Summit.

${ }^{60} \mathrm{OAU}$, Declaration on the Framework.

${ }^{61}$ High Authority of the Transition (HAT), Note sur le dénouement de la crise malgache et sur les perspectives d'avenir de la transition (Antananarivo, Madagascar: mimeo, 2009).

${ }^{62}$ Author's interview with former member of the diplomatic corps, 8 July 2015, Paris.

${ }^{63}$ France Diplomatie, Audition du Ministre des affaires étrangères et européennes, Bernard Kouchner, devant la Commission des affaires étrangères de l'Assemblée nationale (18 March 2009), available at: \{www.diplomatie.gouv.fr/fr/salle-depresse/\}; France Diplomatie, Audition du Ministre des affaires étrangères et européennes, Bernard Kouchner, devant la Commission des affaires étrangères, de la défense et des forces armées du Senat (18 March 2009), available at: \{www.diplomatie.gouv.fr/ fr/salle-depresse/\}; France Diplomatie, Conséquences de la crise économique et financière en matière de sécurité et de défense, audition du Ministre des affaires étrangères et européennes, Bernard Kouchner, devant la Commission des affaires étrangères, de la défense et des forces armées du Senat (2 April 2009), available at: \{www.diplomatie.gouv.fr/fr/salle-depresse\}.

${ }^{64}$ SADC, Communiqué of the Extraordinary Summit of SADC Heads of State and Government 30 March 2009 (Mbabane, Swaziland: Southern African Development Community, 2009); 'Armée "réconciliée": Solidaire contre d'éventuelles interventions armées de la SADC', Madagascar Tribune (28 March 2009), available at: \{www.madagascar-tribune.com/ Solidairecontre-d-eventuelles, 11539.html\}.
} 
dialogue ${ }^{65}$ and a 'consensual and inclusive transitional period' leading to elections and the installation of a new government. Mozambique's former president, Joaquim Chissano, was appointed chief mediator to work on getting this demand implemented. In September 2011, the so-called SADC Roadmap for Ending the Crisis was signed by eight political parties and two of the former presidents. In December 2013, presidential and legislative elections were held and in January 2014 the AU PSC officially declared that constitutional order had been successfully restored. ${ }^{66}$

In the following three subsections, I analyse the rationalities and practices by which constitutional order in Madagascar was finally restored as well as their effect on the conduct of Malagasy political actors and order on the island more generally. As I will demonstrate, the powerful effect of the enactment of the AU's authority to govern coups amounts to prescribing an imaginary of political order that equates legitimate order with the installation of an elected government and the inscription of Malagasy actors into putting this order into place. In having such effects, the AU's authority was neither enacted top-down nor coercively, but in a distant and diffuse manner, drawing on 'ownership' and 'inclusion' of Malagasy actors and enlisting other international actors' diplomatic, technical, and financial support.

\section{Prescribing an imaginary of order}

In early May 2009, AU special envoy Ablassé Ouédraogo opened the first rounds of negotiation in Antananarivo by remarking that their aim was to reach a consensual charter that: (1) guaranteed stability and durable peace in Madagascar; and (2) led to transitional elections. ${ }^{67}$ In the same vein, in July 2009, Joaquim Chissano's mandate stipulated that 'the work of the SADC Facilitator should be finalised upon completion of the inclusive dialogue and holding of the general elections in Madagascar. ${ }^{68}$ The dominant way in which constitutional order was re-established thus reflected the AU's overall rationality for outlawing coups: that people should have the right to choose how and by whom they want to be governed. As a consequence, the AU's approach to restoring constitutional order in Madagascar drew on two main techniques: (1) inclusive intra-elite power sharing; and (2) the organisation of elections. These techniques employed to resolve the political crisis in Madagascar become visible in the focus of the AU's political attention and the strategies and practices employed by those officially charged with realising the AU's claim to govern coups in this particular case.

From the very beginning, resolving the Malagasy crisis was approached as a matter of intra-elite power sharing. For this purpose, the international mediators decided that the re-establishment of constitutional order should take place among the so-called quatre mouvances, the negotiating parties of Rajoelina, Ravalomanana, and the two former presidents Didier Ratsiraka and Albert Zafy. The rationale behind this format was that re-establishing constitutional order should be based on a negotiated solution with the greatest acceptance by and support from Malagasy elites (and by extension the larger population). ${ }^{69}$ The negotiations, as also reflected in the above paraphrased remarks by AU envoy Ouédraogo, were meant to agree to an institutional arrangement and a division of posts among the four negotiating parties, which should then lead

\footnotetext{
${ }^{65} \mathrm{AU}$ PSC, Communique of the $237^{\text {th }}$ Meeting of the Peace and Security Council, PSC/PR/(COMM-2 (CCXXXVII) (Kampala, Uganda: African Union, 2010); SADC, Double Troika Summit Communiqué (Maputo, Mozambique: Southern African Development Community, 2010).

${ }^{66} \mathrm{AU}$ PSC, Communique of the $415^{\text {th }}$ Meeting of the Peace and Security Council, PSC/PR/COMM (CDXV) (Addis Ababa, Ethiopia: African Union, 2014).

${ }^{67}$ Mouvance Zafy, Procès verbal des résultats des pourparlers du Carlton, Antananarivo, 20-22 mai 2009 (Antananarivo, Madagascar: mimeo, 2009).

${ }^{68}$ SADC, SADC Mediation Efforts in Madagascar: Draft Report 7 July-10 August 2009, SC-A87.3 (Gaborone, Botswana: Southern African Development Community, 2009), p. 3.

${ }^{69}$ Author's interview with adviser to the AU special envoy, Antananarivo, 17 February 2014; author's interview with former OIF expert, Antananarivo, 10 March 2014; author's interview (via Skype) with former UN official, 27 August 2014.
} 
to the organisation of transitional elections. Consecutive draft agreements presented by the mediators thus focused on the institutional make-up of the transition and a potential division of posts. But since none of the parties was pressured to agree and to concede too much to the other sides, the negotiations soon stalled. The rationale of resolving the political impasse by an 'inclusive' and negotiated solution, however, was retained over the course of the entire almost five years and so the main task for the mediator(s) was to find the right formula for dividing posts and securing acceptance by those deemed relevant for re-establishing constitutional order in Madagascar (see next subsection).

Apart from 'inclusive' power-sharing, the organisation of transitional elections was regarded as the main means for resolving the political crisis in Madagascar. In fact, the mandate of mediator Chissano quoted above explicitly stated that the final goal of his mission was the holding of elections. In this sense, the negotiations also focused on how to organise elections (quickly) rather than for what purpose to do so. As observed by one interview partner, there was an immediate 'obsession' with elections, which was soon treated as a cure in itself rather than as path to something else. ${ }^{70}$ The focus on elections as the main means for resolving the political crisis on the island meant that the re-establishment of constitutional order came to be equated with the organisation of elections. In fact, the roadmap signed in September 2011 to finally pave the way for transitional elections turned this 'obsession' into a legal text by prescribing that the transitional government was required to create 'the necessary conditions for credible, fair, and transparent elections [and shall actually] refrain from making new long-term commitments. ${ }^{71}$ As a result, questions pertaining to longer-term and structural changes in the organisation of Madagascar's political and social life were explicitly excluded from the transitional programme.

As indicated in the observation on the international 'obsession' with elections, in Madagascar the question how constitutional order ought to be re-established was in fact answered in diverging ways among the country's political elite and population in general. While it might have been a general consensus that any future government would have to be legitimated through democratic elections, there was no consensus that the transition should be reduced to the organisation of elections, in other words, that transition was the organisation of elections. ${ }^{72}$

In April 2009, for instance, the so-called Assises nationales - national consultations organised by the HAT government - demanded a human rights charter and a new constitution, the evaluation of the socioeconomic causes of the crisis, as well as a national conference on reconciliation. ${ }^{73}$ In a similar vein, several civil society organisations, as well as participants in the negotiations themselves repeatedly requested greater attention to the issue of reconciliation as the principle underpinning the search for a new way of organising politics in Madagascar. Here, reconciliation did not refer merely to confidence-building measures among the political elite, but rather to a process of dialogue to identify the multiple forms and causes of societal exclusion. ${ }^{74}$ This was based on the observation that Malagasy society was deeply divided along socioeconomic, cultural, and politico-spatial lines, which had functioned as effective mechanisms of marginalisation and exclusion throughout Madagascar's postcolonial history. ${ }^{75}$ Another round

\footnotetext{
${ }^{70}$ Author's interview with member of CNOSC, Antananarivo, 24 March 2014.

${ }^{71}$ SADC, SADC Roadmap for Ending the Crisis in Madagascar (Antananarivo, Madagascar: Southern African Development Community, 2011), Art. 8.

${ }^{72}$ Author's interview with member of CNOSC, Antananarivo, 13 March 2014; author's interview with member of mouvance Ravalomanana, Antananarivo, 14 March 2014; author's interview with member of ESCOPOL, Antananarivo, 21 March 2014; author's interview with member of mouvance Zafy, Antananarivo, 22 March 2014.

${ }^{73}$ Various, Assises nationales 2-3 avril 2009 (Antananarivo, Madagascar: mimeo, 2009).

${ }^{74}$ Mouvance Zafy, Mémorandum par la Mouvance Albert Zafy pour une délégation de parlementaires UE-ACP sur la situation de la crise, juillet 2010 (Antananarivo, Madagascar: mimeo, 2010).

${ }^{75}$ Author's interview with member of CNOSC, Antananarivo, 17 March 2014; author's interview with member of mouvance Zafy, Antananarivo, 22 March 2014; Mouvance Zafy, Mémorandum par la Mouvance Albert Zafy; Anaclet Imbiki, La réconciliation nationale à Madagascar: Une perspective complexe et difficile (Paris: L'Harmattan, 2015).
} 
of regional consultations, organised in June 2010, demanded that the transition should involve the return of sociocultural and moral values in order to establish a society 'without pain' as well as sustainable development and a fair distribution of Madagascar's riches. ${ }^{76}$ Thus, contrary to the AU's focus in re-establishing constitutional order in Madagascar, these voices saw ending historical injustices and marginalisation as well as dealing with the socioeconomic dimension as crucial steps for resolving what for them constituted the island's 'crisis.'

In monitoring the transition the AU PSC recognised such a general need for reconciliation. ${ }^{77}$ It also noted that the crisis had exacerbated the socioeconomic situation in Madagascar and that by 2012 more than 90 per cent of Malagasies lived below the poverty line of US\$2 a day. ${ }^{78}$ However, both aspects were only invoked in order to increase the pressure on the transitional government to organise elections 'as rapidly as possible' and thus finally achieve re-establishment of constitutional order. ${ }^{79}$ In line with this, the Malagasy Reconciliation Council, established by the Roadmap in order to 'begin healing past individual and collective wounds ${ }^{\prime 80}$ did not receive international funding as promised. In a similar vein, the National Solidarity Fund, set up in order to compensate victims of the state-induced violence that preceded the fall of Ravalomanana and their families, remained empty until constitutional order was finally re-established. ${ }^{81}$ The AU - as guarantor of the Roadmap - did not apply any pressure to implement these provisions of the Roadmap, unlike for the one on the organisation of elections.

In sum, the immediate focus of the path for resolving the political crisis in Madagascar was intra-elite power sharing and the organisation of elections. This was reflected in the general terms set for resolving the political crisis in Madagascar as well as the concrete techniques and practices that defined how and with whom this would take place. Thus, on the ground, the effect of the AU's authority to govern coups was not restricted to the successful re-establishment of legal order. Rather, the AU's authority ultimately served to prescribe a particular imaginary of political order that effectively specified which conflicts were deemed relevant to solving the country's political crisis. This imaginary equates legitimate order with the installation of an elected government. Yet its power did not lie merely in its substantive prescriptions, but also - or more importantly - in the exclusions it necessitated. Through these it effectively shaped how politics and society will (not) be organised in the future, that is, how and by whom Malagasies will be governed in the years to come.

\section{Inscribing Malagasy actors: Ownership and inclusion}

This particular approach to restoring constitutional order in Madagascar was by no means the result of external demands that were imposed on passive Malagasy actors. Rather, the mandate of chief mediator Joaquim Chissano was 'to encourage the Malagasy stakeholders to take the lead of the inclusive dialogue and work to ensure that the Malagasy people take full ownership of the process'. ${ }^{82}$ These ideals of inclusivity and ownership and their implementation in multiparty negotiations constructed subject positions through which Malagasy actors became inscribed

\footnotetext{
${ }^{76}$ Coalition of civil society organisations (COSC), Résultats du Dinika Santatra (Antananarivo, Madagascar: Coalition des organisations de la société civile, 2010), p. 16.

${ }_{77}$ AU PSC, Communique of the $355^{\text {th }}$ Meeting of the Peace and Security Council, PSC/PR/COMM.1 (CCCLV) (Dar es Salaam, Tanzania: African Union, 2013).

${ }^{78}$ AU PSC, Communique of the $394^{\text {th }}$ Meeting of the Peace and Security Council, PSC/PR/COMM (CCCXCIV) (Addis Ababa, Ethiopia: African Union, 2013).

${ }^{79}$ AU PSC, Communique of the $368^{\text {th }}$ Meeting of the Peace and Security Council, PSC/MIN/COMM (CCCLXVIII) (Addis Ababa, Ethiopia: African Union, 2013).

${ }^{80}$ SADC, Roadmap, Art. 25.

${ }^{81}$ Author's interview with FFM official, Antananarivo, 26 March 2014; author's interview with AU official, Antananarivo, 21 February 2014.

${ }^{82}$ SADC, SADC Mediation Efforts, p. 3.
} 
into the making of the post-coup order in Madagascar. However, as mentioned above, those targeted by the AU's demand for a Malagasy owned, speedy return to constitutional order initially resisted following suit. After several rounds of failed efforts, Rajoelina declared in December 2009 that the time for negotiations was over and that, after all, the allocation of posts in transitional institutions was an internal Malagasy matter. ${ }^{83}$

This deadlock at the negotiating table invited others to assume the envisaged ownership and to take responsibility for the re-establishment of Malagasy constitutional order. Under the umbrella of the Espace de concertation des organisations et partis politiques (Space for Consultation of Political Organisations and Parties, ESCOPOL), several members of the political elite who had initially sided with HAT-President Rajoelina used the latter's resistance to the international demand for a negotiated solution with Ravalomanana by portraying themselves as a neutral, inclusive, and cooperative alternative. Political parties, they argued, were the ultimate vehicles for resolving a political crisis like the Malagasy one. ${ }^{84}$ This was a clear break with the hitherto dominant format of the mediation and its focus on intra-elite power sharing between Rajoelina and the former presidents.

What followed was an unprecedented dynamic in the Malagasy party system as the creation of parties became the main means of integration into the transition. Membership in ESCOPOL suddenly rose from nine to more than one hundred political parties, all demanding a role in the conduct of the transition. ${ }^{85}$ In a similar vein, the number of registered parties in Madagascar rose between 2010 and 2011 from fewer than one hundred to more than three hundred. ${ }^{86}$ Rajoelina himself also made use of this dynamism. In summer 2010 he signed a deal with more than 160 political parties, including ESCOPOL, who confirmed him as president of the transition. In turn they were guaranteed a seat in the transitional institutions. ${ }^{87}$ Of those parties that signed the agreement with Rajoelina, only 15 had previously existed. Rajoelina called this alliance with (new) political parties 'nouvelle inclusivité' - the new inclusivity. An internal HAT memorandum explains,

The transitional regime has been and today still is facing a major problem: the recognition of the international community. ... The international community wanted the crisis to be solved in a consensual way. Several attempts have been made in this direction but have failed, or have not been followed by implementation. ${ }^{88}$

The 'new inclusivity' thus promised to be a solution to both the AU's demand for a consensual and inclusive transition and Rajoelina's reluctance to concede too much to the former presidents, Ravalomanana in particular. More importantly, however, it also allowed new actors to become part of the transition and the organisation of elections.

Members of ESCOPOL and leaders of other newly created parties thus claimed that they should be the legitimate drivers of the transition and called upon AU and SADC to recognise this role.

\footnotetext{
${ }^{83}$ La composition du gouvernement est une affaire interne', Madagascar Tribune, available at: \{https://www.madagascartribune.com/La-composition-du-gouvernement-est-une-affaire-interne\}.

${ }^{84}$ Space for Consultation of Political Organisations and Parties (ESCOPOL), Espace de concertation des organisations et partis politiques: Documentation du travail (Antananarivo, Madagascar: mimeo, 2011), pp. 4-5.

${ }^{85}$ ESCOPOL, Espace de concertation, pp. 40-1.

${ }^{86}$ Olivia Rajerison, La légitimation démocratique $d u$ pouvoir à Madagascar (Antananarivo, Madagascar: Friedrich-Ebert-Stiftung, 2013), p. 14.

${ }^{87}$ République de Madagascar, Ordonnance No. 2010-010 relative à la mise ne place du Parlement de la Transition (Antananarivo, Madagascar: mimeo, 2010).

${ }^{88} \mathrm{HAT}$, Mémorandum sur l'évolution de la situation de crise à Madagascar (Antananarivo, Madagascar: mimeo, 2011), p. 8 , translation by the author.
} 
In August 2010, mediator Chissano reminded the two organisations of the 'necessity of broadening the participation to include other stakeholders beyond the Mouvances' and that a 'strategic adjustment in the mediation approach is needed'. ${ }^{89}$ Similarly Chissano's envoy, Leonardo Simão, referred to the emergence of new political actors who 'demanded their right to play a role in efforts to find a solution to the crisis' and who had 'compelled [the mediators] to accept these new political actors'. ${ }^{90}$ In the following months, the mediators presented draft versions of the SADC Roadmap, the document that finally defined the path to transitional elections, to representatives of a plethora of political parties in search of their consent to the organisation of transitional elections both 'rapidly' and 'inclusively'. Consequently, in March 2011 the SADC Summit urged 'all political parties to cooperate and to support the work of the SADC mediation with the perspective of holding free, fair, and credible elections. ${ }^{91}$ In July 2011 the AU PSC thanked the mediator for 'his efforts to reach an as consensual and inclusive solution as possible. ${ }^{92}$ The Roadmap was finally signed by ten signatories, one of them ESCOPOL itself, half of which were political parties established only a few months before. The tangible effect of this new inclusivity was that transitional institutions had to be gradually expanded. For instance, the Malagasy legislature grew from 160 to 526 seats in the final stage of the transition, while the number of ministerial portfolios underwent a similar rise over the course of the transitional period. $^{93}$

In sum, the AU's demand for an inclusive and consensual transition owned by Malagasies themselves created new subject positions for the Malagasy political elite - the consensual and inclusive implementers - and encouraged their inscription into the return to constitutional order through the creation of new parties and the expansion of transitional institutions. Those finally signing the SADC Roadmap were neither fully coerced into doing so nor did they act merely on their own terms. As also observed by mediator Chissano, 'many [of those willing to sign the Roadmap] may have been motivated by the possibility of having their members integrated into the transitional institutions. ${ }^{, 94}$ At the same time, however, many of them complained about their lack of authorship of the draft of the Roadmap and thus the content of the transition: they were regularly consulted for their opinions but the actual text of the Roadmap never changed and the Roadmap was drafted in English, a language of which none of the parties had adequate mastery. ${ }^{95}$

The AU's demand for an inclusive and consensual transition owned by Malagasies thus provided the terms and justifications for these actors' claims to authority and legitimacy and served as a mechanism of both empowerment and inscription into a transition that was, however, already plotted by someone else. In line with a governmentality perspective, the AU's approach to governing coups through ownership and inclusion was thus subjectivating in the double sense of the term: it empowered a particular section of the Malagasy elite to take on new positions in the transitional institutions of the state yet at the same time restricted their 'possible realm of

\footnotetext{
${ }^{89}$ Joaquim Chissano, Report of the SADC Mediator on the Crisis in Madagascar (Windhoek, Namibia: Southern African Development Community, 2010), p. 34.

${ }^{90}$ Leonardo Simão, Letter to the Three Mouvances (Maputo, Mozambique: mimeo, 2011).

${ }^{91} \mathrm{SADC}$, Réunion du sommet de la Troïka de l'Organe de coopération en matière de politique, défense et sécurité de la SADC (Livingstone, Zambia: Southern African Development Community, 2011).

${ }^{92}$ AU PSC, Press Statement of the $283^{\text {rd }}$ Meeting of the Peace and Security Council, PSC/PR/BR (CCLXXXIII) (Addis Ababa, Ethiopia: African Union, 2011).

${ }^{93}$ Mireille Razafindrakoto, François Roubaud, and Jean-Michel Wachsberger, 'Élites, pouvoir et régulation à Madagascar: Une lecture de l'histoire à l'aune de l'économie politique', Afrique contemporaine, 251 (2014), pp. 25-50 (p. 45).

${ }^{94}$ Joaquim Chissano, Report du médiateur HE Joaquim Chissano preparé pour la réunion du sommet de la Troïka de l'Organe de Coopération en Matière de Politique, Défense et Sécurité de la SADC (Livingstone, Zambia: Southern African Development Community, 2011), pp. 15-16, translated by the author.

${ }^{95}$ Author's interview with member of mouvance Zafy, Antananarivo, 15 March 2014; author's interview with member of ESCOPOL, Antananarivo, 21 March 2014; author's interview with member of mouvance Ravalomanana, Antananarivo, 3 April 2014.
} 
action ${ }^{96}$ to satisfying the demand for restoration of constitutional order by rapidly organising elections.

\section{How AU authority operates on the ground}

From the very beginning, the AU's claim to authority over what counts as legitimate order in Madagascar was questioned by key political figures, not least the HAT government, and it aroused great scepticism among 'ordinary' people, for whom the AU's sudden appearance in Madagascar's politics was surprising. It was therefore not uncommon to portray the AU and other international actors' involvement in the post-coup reordering of Madagascar as a powerful external force - the 'main puissante', the powerful hand - as one interview partner depicted it. ${ }^{97}$ This image of the powerful hand also comes close to the way the authority of international organisations is commonly imagined in IR scholarship that focuses on the capacity to decide rather than the diffuse and often difficult ways in which these formal capacities are actually enacted in practice.

Contrary to both this image in IR scholarship and the popular depiction in Madagascar, however, the enactment of AU authority to govern how constitutional order was restored in Madagascar did not stem from a uniform, intentional, and effective source in Addis Ababa. Rather, the key to the understanding of this form of government, that effectively prescribed a particular imaginary of order and inscribed Malagasy political actors into this order, is the distant, non-subjective, and diffuse way in which it was exercised. Contrary to the perception of the 'main puissante', what Malagasies experienced between 2009 and 2014 was a diffuse form of power that was anchored in the AU's anti-coup regime without being implemented solely by the AU. I will substantiate this argument in two regards.

First, from the perspective of the AU, there was no will to govern the situation in Madagascar more intrusively. In fact, several examples show that the AU actually evaded becoming and acting as such an intrusive external authority. For instance, in 2011 mediator Chissano suggested opening an AU liaison office in Antananarivo so that the continental organisation would be able to follow up more closely what was going on on the ground and exert more pressure on the Malagasy parties to fulfil the demanded return to constitutional order. ${ }^{98}$ The PSC made this demand twice, but no immediate action followed. ${ }^{99}$ The first AU liaison officers arrived in 2013, but their mandate was explicitly not to engage the Malagasy parties. It was only in early 2014 - when constitutional order had officially been restored - that the office head arrived on the island. Thus, despite the wide-ranging consequences of $\mathrm{AU}$ decisions on the situation in Madagascar, the AU did not want to invest more in close surveillance and steering of the situation on the ground. In addition, despite the AU's constant demand for a 'speedy return to constitutional order', the actual signing of the Roadmap was delayed by almost six months because neither the AU nor SADC was prepared to organise a signing ceremony. In fact, the Malagasy parties themselves had to send repeated letters to the chairperson of the AU Commission, demanding that such a signing event be organised. ${ }^{100}$ And finally, several political parties that had accepted the Roadmap as well as Malagasy civil society organisations charged with overseeing the Roadmap's implementation looked in vain for the AU to respond to their complaints about the course of the transition and the infringements against some of the principles enshrined in the Roadmap. ${ }^{101}$ Thus contrary to the demanding and sometimes threatening language of the

\footnotetext{
${ }^{96}$ Foucault, 'The subject and power', p. 790.

${ }^{97}$ Author's interview with member of the mouvance Zafy, Antananarivo, 15 March 2014

${ }^{98}$ Chissano, Report of the SADC Mediator, p. 13; Chissano, Report du médiateur, p. 1.

${ }^{99}$ AU PSC, Press Statement of the Meeting of the $283^{\text {rd }}$ AU PSC, Communique of the $303^{\text {rd }}$ Meeting of the Peace and Security Council, PSC/PR/COMM.1 (CCIII) (Addis Ababa, Ethiopia: African Union, 2011).

${ }^{100}$ Author's interview with member of ESCOPOL, Antananarivo, 21 March 2014.

${ }^{101}$ Author's interview with member of CNOSC, Antananarivo, 17 March 2014.
} 
PSC that 'urges the Malagasy parties to extend full cooperation to the Mediator'102 and 'warns all those who may be tempted to hinder the ongoing process' ${ }^{103}$ of restoring constitutional order, the AU did not develop any more fine-grained measures to actually steer the re-establishment of constitutional order in Madagascar.

Second, in the preceding section, I pointed out that the incorporation of the Malagasy political elite into the prescribed transition through inclusion and ownership was decisive for restoring constitutional order in Madagascar. But, apart from local Malagasy actors, other international actors, too, were crucial for realising the AU's authority to govern coups d'état. On the one hand, the AU repeatedly used the International Contact Group (ICG), a loose international coordination mechanism set up under the aegis of the AU, as a vehicle for establishing its authority over how constitutional order should be restored. In early 2013 for instance, Rajoelina filed his candidacy in the upcoming transitional elections. This decision went against the AU's anti-coup regime, which prohibits participants in coups from presenting themselves in elections. ${ }^{104}$ In enforcing its norm, the AU revitalised the ICG, which had until then not played any important role in Madagascar. This time, however, the ICG confirmed the AU's norm and threatened that they would neither fund nor recognise the elections and would apply targeted sanctions against Rajoelina. ${ }^{105}$ This threat was ultimately successful: Rajoelina abandoned his plans and transitional elections were held in line with the AU's prescriptions.

On the other hand, and contrary to this enlisting of international support for AU commands, the AU's approach that prescribed the return to constitutional order in a particular way but was distant in enforcing it, created space for other international actors to carry out the enforcing or implementing role. For instance, the AU's limited knowledge about and experience in Madagascar before March 2009 and the organisation's confrontational stance towards the HAT government made it difficult to reach out to the Malagasy parties. The lack of presence on the ground furthered this disadvantage the AU had in comparison with other international actors such as the European Union or the United Nations, which had permanent missions, staff familiar with the Malagasy political landscape, and established local contacts. ${ }^{106}$ As a consequence, much of the everyday activities accompanying the return to constitutional order were in fact carried out by bodies other than the AU. The negotiations among Malagasy political actors ahead of and after the signing of the Roadmap, for instance, were facilitated by diplomats from the Indian Ocean Commission (COI), while coordination within the local chapter of the ICG, for instance, took place under the auspices of the EU. ${ }^{107}$ Not least, many steps necessary for realising the re-establishment of constitutional order - the official negotiation rounds, the local liaison offices, the meetings of the ICG - were in fact financed by the EU or other European donor countries. ${ }^{108}$ In a similar vein, the transitional elections demanded by the AU were technically organised by UNDP and the OIF, while more than 15 organisations and donor countries contributed a total of US\$26 million to the actual conduct of such elections. ${ }^{109}$

This makes it apparent that enacting AU authority did not stem from a single, intentional, and powerful source. Instead, the AU's authority to govern coups was carried out in a distant, non-

\footnotetext{
${ }^{102}$ AU PSC, Communiqué of the $237^{\text {th }}$ Meeting.

${ }^{103}$ AU PSC, Communiqué of the $394^{\text {th }}$ Meeting.

${ }^{104} \mathrm{AU}$, African Charter, Art. 25(4).

${ }^{105}$ 'Sortie de crise: Les sept commandements du GIC', L'Express de Madagascar (17 July 2013), available at: \{http://fr.allafrica.com/stories/201307181299.html\}.

${ }^{106}$ Author's interview with EU official, Antananarivo, 13 February 2014; author's interview (via Skype) with former UN official, 27 August 2014.

${ }^{107}$ Author's interview with EU official, Antananarivo, 13 February 2014; author's interview with AU official, Antananarivo, 21 February 2014.

${ }^{108}$ Author's interview with EU official, Antananarivo, 13 February 2014; author's interview with member of the diplomatic corps, Antananarivo, 21 March 2014; author's interview with former diplomat, Paris, 8 July 2014.

${ }^{109}$ Author's interview with UNDP official, Antananarivo, 11 February 2014; author's interview with OIF official, Antananarivo, 25 February 2014.
} 
subjective, and diffuse manner, drawing on both local 'ownership' and 'inclusion', as well as diplomatic, technical, and financial action by other international actors, such as the EU, UN, and COI. All this worked towards fulfilling the AU's demand for rapidly re-establishing constitutional order, which, despite emanating from the AU, was by no means carried out by the AU alone. What counted in Madagascar were less the AU's prescriptive or punitive capacities, but the diffuse and open network of multiple agents and agencies who all became involved in re-establishing constitutional order in a particular way and in excluding alternatives.

\section{Conclusion}

Order in post-2009 Madagascar cannot be understood without the African Union's growing authority, in particular the organisation's authority to govern coups d'état. However, the reverse is also true. The relevance of this authority, so the argument of this article, cannot be understood without considering how and with what effects it materialises 'on the ground', that is, its effects on the societies addressed by the AU's political norms. International Relations scholars studying the growing authority of international organisations have so far paid little attention to these (societal) effects of IO authority.

Seeking to address this lacuna, I suggested analysing the AU's authority from the perspective of governmentality, which draws attention to the rationalities and techniques through which the AU's claim to govern coups is realised as well as the subjectivating - that is, simultaneously enabling and constraining - effects this has on those affected by the demanded return to constitutional order. Unlike the hitherto dominant focus in IR scholarship on formal decision-making powers and those (organisations or individuals) possessing them, a governmentality perspective draws attention to the distant and diffuse ways of and the active involvement of those governed in realising governmental claims.

The enactment of AU authority in Madagascar demonstrates that this authority is indeed effective through both prescription and inscription. On the one hand, it prescribed a particular model of political order that focused on realising people's right to choose how and by whom they want to be governed by promoting inclusive power-sharing and elections as measures for dealing with political conflicts. This structured not only the way 'la crise malgache' was (not) resolved but also how and by whom Malagasies will be governed in the years to come. And it effectively blocked alternative efforts addressing the political crisis in Madagascar. On the other hand, the AU's demand to re-establish constitutional order was only realised through the inscription of Malagasy actors based on the principles of inclusivity and ownership. While none of them was coerced into obedience, their realm of action was also restricted to fulfilling the AU's demand for an inclusive and consensual transition and quickly setting up elections. Close examination of the concrete enactment of AU authority on the ground also showed that the AU's desire to exert its influence on coups was realised in a distant and diffuse way, in which a variety of national and international actors were involved and in which the AU effectively evaded governing the situation in Madagascar more intrusively. In sum, the enactment of AU authority had far more general consequences for politics and order on the island than the 'sovereign imaginary' and a focus on the AU's compulsory power vis-à-vis putschists and those infringing the African anti-coup norm would suggest. While the AU's legal and formal capacities were crucial for why the organisation became involved in restoring constitutional order in Madagascar, neither the way AU authority was put into practice, nor its effects can be attributed to these formal capacities alone.

These observations have several implications for the study of IO authority. Firstly, they demonstrate the importance of a relational and decentralised perspective on authority that departs from the still widespread fixation in the literature on formal capacities and assumed locales of authority. Instead, the case of the AU in Madagascar underlines that even where such formal capacities exist, their enactment can take place in diffuse and networked ways involving a wide 
variety of other actors. The multiplicity of agencies in the international realm in fact makes this form of international authority empirically more likely than forms based on the ideals of domestic state authority. ${ }^{110}$ In a similar vein, Nico Krisch called for studying more 'liquid' forms of authority, 'characterized by a lower degree of consolidation and a significant dynamism in the configuration of authority structures'. ${ }^{11}$ Nonetheless, contrary to what the binary opposition between 'liquid' and 'solid' authority suggests, I demonstrate that the 'liquid' nature of the practical enactment of the AU's claim to govern coups was not the result of a lack of formal or solid authority, but a particular mode of governing by involving national actors and enlisting international support for a purpose already defined by the AU's anti-coup regime. Thus, the diffuse and networked implementation of IO authority may in fact be not the alternative to, but part of the growing formalisation and institutionalisation of international claims to authority.

Secondly, the AU's authority to govern coups also underlines the shortcomings of what I have called the 'sovereign imaginary' for understanding IO authority. In the concrete case at hand, the AU's authority is neither autonomous from nor merely exercised upon African states. But this is also not to say that the state does not matter for understanding AU authority - in fact, quite the contrary is true. After all, the PSC - the main decision-making organ for all matters related to unconstitutional changes of government - is an intergovernmental body made up of state representatives. Thus, even formally the enactment of the AU's authority is not autonomous from states. More importantly, and in contrast with the focus on IO authority over states, the governmentality perspective employed in this article shows how the AU's authority to govern coups is exercised simultaneously on states and societies by defining and enacting a particular rationality of how states should be governed and how citizens in these states should behave.

Thirdly, the empirical results also underline the fact that neither the way IO authority is exercised nor its effects can be inferred merely from the formal capacities that are vested in an IO. By concentrating on formal and legal powers for understanding IO authority, IR scholarship has so far limited itself in its efforts to fully comprehend the power effects of international authority and has thus ignored the tangible realities international authority creates for the lives of many people around the globe. However, studying these effects of international authority is crucial not only for achieving a more complete picture of international authority. It is also important because the question of 'how we are governed' also implies the question of how it could be different. Understanding and revealing the effects of international authority, the way it creates subjectivities and shapes conduct, is thus also a normative and political endeavour. It makes critical analysis possible and at least activates thinking about alternatives. Especially at a time when the growing authority of international institutions is increasingly contested from various sides, ${ }^{112}$ this would be an important field in which IR scholarship could demonstrate its relevance by carrying out the analytical groundwork for a constructive and transformative rather than a regressive critique of international authority and the existing institutional order currently in place. However, such a turn towards a more detailed and fine-grained understanding of the different workings (and manifestations) of international authority on subjects other than states and in specific places also involves increased valorisation of in-depth and comprehensive empirical work. It also requires paying more attention to the non-Western world in which the intrusive imprint of the international has been evident since long before the term 'global governance' became prominent in IR's vocabulary.

\footnotetext{
${ }^{110}$ Nicholas Onuf and Frank F. Klink, 'Anarchy, authority, rule', International Studies Quarterly, 33:2 (1989), pp. 149-73.

${ }^{111}$ Krisch, 'Liquid authority', p. 238.

${ }^{112}$ Liesbet Hooghe, Tobias Lenz, and Gary Marks, 'Contested world order: The delegitimation of international governance', Review of International Organizations, 14:4 (2019), pp. 731-43; David H. Bearce and Brandy J. Jolliff Scott, 'Popular nonsupport for international organizations: How extensive and what does this represent?', The Review of International Organizations, 14:2 (2019), pp. 187-216.
} 
Acknowledgements. I would like to thank my interview partners for making this research possible; and for their valuable comments on earlier versions of this manuscript I thank Felix Anderl, Micha Wiebusch, the participants of the workshop 'Beyond Anarchy: Rule and Authority in the International System' at Goethe University Frankfurt, Germany, as well as the two anonymous reviewers and the editorial team of this journal.

Antonia Witt is a Senior Researcher and Head of the Research Group 'African Intervention Politics' at the Peace Research Institute Frankfurt (PRIF). Her research focuses on the authority and legitimacy of international and regional organisations, Global IR, the African Peace and Security Architecture, and the local politics of African interventions. She is the co-author of International Organizations under Pressure (Oxford University Press, 2019) as well as the author of Undoing Coups (Zed Books, 2020); she has published in journals including Millennium, Journal of Intervention and Statebuilding, and the South African Journal of International Affairs.

Cite this article: Witt, A. 2022. Beyond formal powers: Understanding the African Union's authority on the ground. Review of International Studies 48, 626-645. https://doi.org/10.1017/S0260210522000067 